\title{
Kualitas Hidup Satu Tahun Pasien Kanker Serviks yang Telah Dilakukan Histerektomi Radikal di RSUP Dr. Sardjito, Yogyakarta
}

\author{
Afif Fuadi $^{1}$, Heru Pradjatmo ${ }^{2}$, Ardhanu Kusumanto ${ }^{3}$ \\ 1,2,3 Departemen Obstetri dan Ginekologi FK-KMK UGM \\ Korespondensi: dr.afiffuadi@gmail.com
}

Submisi:6 September 2019; Revisi:21 November 2019; Penerimaan: 22 November 2019

\begin{abstract}
Background: Cervical cancer is the most common cancer found in a woman. Overall more than $85 \%$ occur in developing countries.The highest incidence in Sub-Saharan Africa, Latin America and the Caribbean, Melanesia and West Asia, Australia / New Zealand. Large geographical variations reflect the availability of screening that makes it possible to detect precancerous lesions and the prevalence of infection with Human Papillomavirus (HPV). Screening modalities and treatment strategies have evolved, with the advent of current therapies that include surgery, chemotherapy and radiation, cervical cancer patients are faced with complete post-treatment side effects. So it can degrade their quality of life.

Objective: To know quality of life one year of cervical cancer patients who have done radical hysterectomy

Methods: quantitative research with cross sectional approach with by conducting interviews with patients while checking on polyclinic oncology using instrument from EORTC QLQ C30 version 3

Result adn discussion: Cervical cancer patients aged 45-55 years are 21 people (37.5\%), not menopausal, with parity between 1-2 and a normal body mass index. The most common type of histopathology is squamous cell carcinoma. Mostly no lymphatic disorders, no lymphovascular space invasion (LVSI) and no adjuvant chemotherapy. The quality of life cervical cancer. The quality of life of cervical cancer patients in good categories with an average global health status rate $>87.5 \%$ and on the functional and symptom scale domain $>90 \%$. There is only significant relationship shown in the age variable with the value of $p=0,020$ and $R R=0,545$ and the involvement of lymph nodes with $p=0.008$.
\end{abstract}

Conclusion: In this study the quality of life of cervical cancer patients who have done radical hysterectomy in Dr. Sardjito is very good.

Keywords: Cervical Cancer; Quality of Life; Radical Hysterect

\begin{abstract}
ABSTRAK
Latar Belakang: Kanker serviks merupakan kanker paling banyak ketiga yang ditemukan pada seorang wanita. Secara keseluruhan lebih dari $85 \%$ terjadi pada negara-negara berkembang. Insidensi rata-rata paling tinggi di wilayah Sub Sahara Afrika, Amerika Latin dan Karibia, Melanesia dan Asia Barat, Australia/Selandia Baru. Variasi geografis yang besar mencerminkan ketersediaan skrining yang memungkinkan untuk mendeteksi lesi prakanker dan prevalensi terjadinya infeksi Human Papillomavirus (HPV). Modalitas skrining dan strategi pengobatan telah berevolusi, dengan kemajuan terapi saat ini yang meliputi tindakan pembedahan, kemoterapi dan radiasi, penderita kanker serviks dihadapkan pada efek samping pasca pengobatan lengkap, YANG dapat menyebabkan penurunan kualitas hidup mereka.

Tujuan: Mengetahui kualitas hidup satu tahun pasien kanker serviks yang telah dilakukan histerektomi radikal.

Metode: Penelitian kuantitatif dengan pendekatan cross sectional dengan cara melakukan wawancara dengan pasien saat periksa di poli onkologi menggunakan instrumen dari EORTC QLQ C30 versi 3.

Hasil dan Pembahasan: Rata-rata penderita kanker serviks berusia 45-55 tahun yaitu 21 orang (37,5\%), tidak menopause, dengan paritas antara 1-2 dan indeks massa tubuh normal. Jenis histopatologi terbanyak adalah karsinoma sel skuamosa dengan grade sedang. Sebagian besar tidak terdapat keterlibatan kelenjar getah bening, lymphovascular space invation (LVSI) dan tidak dilakukan kemoterapi adjuvan. Kualitas hidup pasien kanker serviks termasuk dalam katagori baik dengan nilai rata-rata status kesehatan global $>87,5 \%$ dan pada domain skala fungsi dan gejala $>90 \%$. Hanya saja terdapat hubungan yang bermakna yang ditunjukkan pada variabel dengan nilai $p=0,020$ dan $R R=0,545$ dan keterlibatan kelenjar getah bening dengan nilai $p=0,008$.
\end{abstract}

Kesimpulan: Pada penelitian ini kualitas hidup pasien kanker serviks yang telah dilakukan histerektomi radikal di RSUP Dr. Sardjito sangat baik.

Kata kunci: Kanker servik; Kualitas Hidup; Histerektomi radikal. 


\section{PENDAHULUAN}

Kanker serviks merupakan kanker ketiga yang paling banyak ditemukan pada seorang wanita, dengan estimasi sekitar 529.828 ditemukan kasus baru dan 275.128 terjadi kematian yang dilaporkan di seluruh dunia pada tahun 2008. Lebih dari $85 \%$ secara global terjadi di negara-negara berkembang, dimana menyumbangkan $13 \%$ dari jumlah keseluruhan kanker pada wanita. Pada negara berkembang, standar usia terjadi kematian berkisar 10/10.000 tiga kali lebih tinggi dibandingkan dengan negara maju. ${ }^{1}$

Kanker serviks merupakan suatu terminologi untuk suatu neoplasia ganas yang berkembang dari sel di dalam serviks uteri. Salah satu gejala yang paling umum kanker serviks adalah perdarahan abnormal yang keluar dari vagina, tetapi pada beberapa kasus gejala-gejala tersebut mungkin tidak jelas sampai dengan kanker berkembang ke arah stadium lanjut. Pengobatan kanker serviks biasanya terdiri atas pembedahan (termasuk lokal eksisi) pada stadium awal, dan kemoterapi dan/atau radioterapi pada stadium lanjut penyakit.

Serviks menghubungkan uterus dengan vagina (jalan lahir). Bagian serviks yang tertutup oleh bagian tubuh uterus disebut juga dengan endoserviks. Kemudian bagian luar disebut juga eksoserviks. Terdapat dua tipe sel inti yang meliputi serviks yaitu sel skuamosa (pada endoserviks). Tempat dimana dua jenis sel ini bertemu yang disebut juga dengan zona transformasi. Paling banyak kanker serviks berawal dari zona transformasi ini. Sebagian besar kanker berawal dari sel yang menghubungkan serviks, dimana sel tidak secara langsung berubah menjadi kanker. Sebagai gantinya, sel normal pada serviks secara bertahap berkembang dari prakanker berubah menjadi kanker. Para dokter menggunakan beberapa terminologi untuk mendeskripsikan beberapa perubahan pra kanker yang berubah menjadi kanker diantaranya Cervical Interepithelial Lesion (CIL) dan displasia. Perubahan ini dapat dideteksi dengan menggunakan PAP tes dan diterapi untuk mencegah perkembangan dari kanker.

Terdapat dua tipe dari kanker serviks yaitu sel skuamosa dan adenokarsinoma. Delapan puluh sampai sembilan puluh persen kanker serviks merupakan karsinoma sel skuamosa. Kanker berasal dari sel skuamosa yang meliputi permukaan dari eksoserviks. Di bawah mikroskop tipe sel kanker ini menyerupai sel-sel skuamosa. Sebagian kanker serviks lainnya adalah adenocarsinoma yang lebih banyak terjadi dalam rentang 20-30 tahun terakhir. ${ }^{2}$

Infeksi (HPV) Human Papillomavirus merupakan penyebab seluruh kejadian kasus kanker serviks dan penyebab keganasan non serviks tertentu meliputi kanker vulva, vagina, penis, anus, dan orofaring. Infeksi HPV yang terkait dengan kanker didominasi oleh kanker serviks yang tersebar di seluruh dunia. Diperkirakan $80 \%$ angka kejadian kanker serviks adalah penyebab kematian wanita yang dihubungkan dengan kanker. Program skrining pada negara-negara industri secara substansial menurunkan insidensi dan mortalitas dari kanker serviks. Penurunan kanker serviks di kombinasikan dengan peningkatan insidensi HPV terkait erat dengan kejadian kanker anus dan orofaring, yang meningkat tiga kali lipat lebih tinggi antara tahun 1988 sampai dengan 2004. Insidensi HPV terkait dengan kanker non serviks serupa dengan kanker serviks di negara-negara industri seperti Amerika Serikat. Lebih dari seperempat yang terjadi pada laki-laki di Amerika Serikat adalah kanker orofaring dan hampir dari setengahnya adalah kanker anus. Proporsi HPV terkait kanker non serviks jauh lebih rendah didalam perkembangannya.

HPV yang terkait dengan keganasan di dominasi oleh kanker serviks, hal ini menyiratkan bahwa sebagian besar dari infeksi HPV merupakan penyebab terjadinya kanker yang terjadi pada wanita. HPV yang menyebabkan keganasan di Amerika Serikat, tidak di dominasi kanker pada satu antomi tubuh saja dan secara substansial minoritas terjadi pada laki-laki. ${ }^{2}$

Modalitas skrining dan strategi pengobatan sebagian besar telah berevolusi saat ini, oleh karena itu pengobatan kanker serviks stadium awal akan lebih efektif. Secara keseluruhan tingkat kelangsungan hidup pada kenyataanya telah meningkat. Pada stadium awal kelangsungan hidup 5 tahun diperkirakan sekitar 91,5\%.

Terapi pengobatan untuk kanker serviks, baik itu pembedahan, radioterapi, atau kemoterapi, menimbulkan toksisitas dan efek samping. Efek samping yang persisten terjadi pada fungsi fisik 
dan juga psikologis pasien terjadi pada saat pengobatan kemoradiasi. Setelah menjalani rangkaian pengobatan lengkap, penderita kanker serviks terkadang mengalami dampak atau efek dari pengobatan tersebut yang menyebabkan penurunan kualitas hidup mereka. Kanker serviks sebagian besar di diagnosis pada wanita usia subur yang masih aktif secara seksual.

Aktifitas seksual selain menyangkut harga diri, juga sangat dipengaruhi oleh perlakuan yang diterima. Oleh karena itu, diskusi dan perencanaan terapi juga harus membahas semua aspek kualitas hidup. Studi kami bertujuan untuk menganalisa dampak kanker serviks terhadap kualitas hidup. ${ }^{3}$

\section{METODE}

Penelitian ini adalah penelitian kuantitatif dengan pendekatan cross sectional. ${ }^{4}$ Penelitian dilakukan di RSUP Dr. Sardjito Yogyakarta dimulai sejak Agustus 2017. RSUP Dr. Sardjito dipilih sebagai lokasi penelitian dikarenakan sebagai RS pusat rujukan pasien-pasien dengan keganasan, sehingga lebih mudah dalam melakukan penelitian. Kriteria inklusi pada penelitian ini adalah pasien kanker serviks stadium awal (IA-IIA), pasien kanker serviks stadium awal dengan bulky tumor yang mendapatkan terapi neoadjuvant, pasien yang melakukan histerektomi radikal. Kriteria eksklusi: terdapat keganasan lain, pasien pernah melakukan operasi lain, pasien dengan obesitas. Pengambilan sampel penelitian dengan cara melakukan wawancara langsung dengan pasien di poliklinik onkologi RSUP Dr. Sardjito. Kemudian kualitas hidup diukur menggunakan instrumen kuisioner dari EORTC QLQ C30 versi 3.

\section{HASIL DAN PEMBAHASAN}

Penelitian ini dilakukan di RSUP Dr. Sardjito Yogyakarta melalui wawancara langsung terhadap penderita kanker serviks saat pasien periksa rutin di poliklinik Onkologi dan Ginekologi. Didapatkan subjek penelitian sebanyak 56 wanita. Karakteristik pasien meliputi umur, menopause, paritas, IMT, stadium kanker, jenis histopatologi, grade, keterlibatan KGB, LVSI, dan kemoterapi ajuvan disajikan pada Tabel 1.

Tabel 1. Karakteristik pasien kanker serviks yang telah dilakukan histerektomi radikal di RSUP Dr. Sardjito

\begin{tabular}{llrr}
\hline & Karakteristik pasien & $\mathbf{n}$ & \multicolumn{1}{c}{$\%$} \\
\hline Umur & 26-35 tahun & 5 & $8,9 \%$ \\
& $36-45$ tahun & 18 & $32,1 \%$ \\
& $46-55$ tahun & 21 & $37,5 \%$ \\
$56-65$ tahun & 9 & $16,1 \%$ \\
& $>65$ tahun & 3 & $5,4 \%$ \\
Menopause & Ya & 22 & $39,3 \%$ \\
\multirow{5}{*}{ Paritas } & Tidak & 34 & $60,7 \%$ \\
& 0 & 5 & $8,9 \%$ \\
& $1-2$ & 25 & $44,6 \%$ \\
IMT & $3-4$ & 23 & $41,1 \%$ \\
& $\geq 5$ & 3 & $5,4 \%$ \\
\multirow{5}{*}{ Stadium Kanker Serviks } & Underweight $(<18,5)$ & 3 & $5,4 \%$ \\
& Normal (18,5-24,9) & 37 & $66,1 \%$ \\
& Overweight $(>24,9)$ & 16 & $28,6 \%$ \\
& IA & 2 & $3,6 \%$ \\
& IB1 & 15 & $26,8 \%$ \\
Jenis Histopatologi & IB2 & 3 & $5,4 \%$ \\
& IIA1 & 26 & $46,4 \%$ \\
& IIA2 & 10 & $17,9 \%$ \\
& Ca sel & 34 & $60,7 \%$ \\
& Squamous & 22 & $39,3 \%$ \\
\hline
\end{tabular}




\begin{tabular}{llcc}
\hline & Karakteristik pasien & $\mathbf{n}$ & $\mathbf{\%}$ \\
\hline \multirow{2}{*}{ Grade } & Baik & 16 & $28,6 \%$ \\
& Sedang & 23 & $41,1 \%$ \\
\multirow{3}{*}{ Keterlibatan KGB } & Buruk & 17 & $30,4 \%$ \\
\multirow{3}{*}{ LVSI } & Ya & 25 & $44,6 \%$ \\
& Tidak & 31 & $55,4 \%$ \\
\multirow{2}{*}{ Kemoterapi adjuvan } & Ya & 13 & $23,2 \%$ \\
& Tidak & 43 & $76,8 \%$ \\
& Ya & 21 & $37,5 \%$ \\
& Tidak & 35 & $62,5 \%$ \\
\hline
\end{tabular}

Dari tabel 1 didapatkan data bahwa rata-rata usia penderita kanker serviks yang masuk dalam subjek penelitian antara 46-55 tahun yaitu 21 orang (37,5\%). Sebagian besar penderita kanker serviks telah mengalami stadium IIA sebanyak 28 orang $(50,0 \%)$ dan belum terjadi menopause yaitu 34 tahun $(60,7 \%)$. Jika penderita dibedakan menurut cut off point 55 tahun, maka didapatkan jumlah penderita 44 orang $(78,6 \%)$ untuk penderita yang berusia di bawah 55 tahun dan 12 orang $(21,4 \%)$ untuk yang berusia diatas 55 tahun. Berdasarkan paritasnya, sebagian besar memiliki paritas antara 1-2 yaitu 25 orang $(44,6 \%)$. Kemudian jenis histopatologi yang paling banyak ditemukan adalah karsinoma sel squamosa yaitu 34 buah $(60,7 \%)$ dibandingkan adenokarsinoma yaitu 22 buah (39,3\%). Penderita kanker serviks sebagian besar memiliki Index Massa Tubuh yang normal meliputi 37 orang $(66,1 \%)$. Proporsi penderita kanker serviks berdasarkan pada grade baik, sedang dan buruk hampir berimbang meskipun proporsi paling banyak pada grade sedang yaitu 23 orang $(40,1 \%)$. Sebagian besar pasien tidak terdapat keterlibatan KGB yaitu 31 orang $(55,4 \%)$, dan tidak terdapat keterlibatan LVSI yaitu 43 pasien $(76,8 \%)$, dan tidak melakukan kemoterapi adjuvant yaitu 35 orang $(62,5 \%)$.

Kualitas hidup wanita penderita kanker serviks yang telah melakukan histerektomi radikal di RSUP Dr. Sardjito diukur menggunakan kuesioner dari EORTC QLQ C30 yang terdiri dari 15 domain, digambarkan pada Tabel 2.

Tabel 2. Kualitas hidup wanita penderita kanker serviks yang telah dilakukan histerektomi radikal di RSUP Dr. Sardjito.

\begin{tabular}{|c|c|c|c|c|c|}
\hline Domain Kualitas Hidup & Mean & $\begin{array}{l}\text { Standard } \\
\text { Deviation }\end{array}$ & Median & Minimum & Maksimum \\
\hline $\begin{array}{l}\text { Status kesehatan global } \\
\text { (kualitas hidup) }\end{array}$ & 87,05 & 7,77 & 83,33 & 66,67 & 100,00 \\
\hline \multicolumn{6}{|l|}{ Skala Fungsi } \\
\hline Fungsi Fisik & 95,30 & 4,75 & 96,67 & 83,33 & 100,00 \\
\hline Fungsi Peran & 96,28 & 6,73 & 100,00 & 66,67 & 100,00 \\
\hline Fungsi Emosional & 95,76 & 4,80 & 95,83 & 83,33 & 100,00 \\
\hline Fungsi kognitif & 95,24 & 6,72 & 100,00 & 66,67 & 100,00 \\
\hline Fungsi Sosial & 98,96 & 3,58 & 100,00 & 83,33 & 100,00 \\
\hline \multicolumn{6}{|l|}{ Skala Gejala } \\
\hline Kelelahan & 93,95 & 6,38 & 94,44 & 77,78 & 100,00 \\
\hline Mual dan muntah & 96,58 & 5,45 & 100,00 & 83,33 & 100,00 \\
\hline Nyeri & 94,49 & 7,33 & 100,00 & 75,00 & 100,00 \\
\hline Dispnea & 99,11 & 3,79 & 100,00 & 83,33 & 100,00 \\
\hline Insomnia & 95,24 & 7,60 & 100,00 & 83,33 & 100,00 \\
\hline Kehilangan selera makan & 96,13 & 7,10 & 100,00 & 83,33 & 100,00 \\
\hline Konstipasi & 95,83 & 8,56 & 100,00 & 66,67 & 100,00 \\
\hline Diare & 98,51 & 4,80 & 100,00 & 83,33 & 100,00 \\
\hline Kesulitan keuangan & 99,11 & 3,79 & 100,00 & 83,33 & 100,00 \\
\hline
\end{tabular}


Pada tabel 2 rata-rata kualitas hidup pada domain status kesehatan global pada wanita penderita kanker serviks yang telah dilakukan histerektomi radikal di RSUP Dr. Sardjito sebesar $87,05 \%$ dengan rentang $66,67 \%-100,0 \%$. Pada domain lainnya dari aspek fungsi yaitu fungsi fisik, fungsi peran, fungsi emosional, fungsi kognitif, fungsi sosial, dan aspek gejala yaitu kelelahan, mual dan muntah, nyeri, dispnea, insomnia, kehilangan selera makan, konstipasi, diare, dan kesulitan keuangan diperoleh rata-rata $>90 \%$. Hal ini menunjukkan bahwa kualitas hidup wanita penderita kanker serviks yang telah melakukan histerektomi radikal di RSUP Dr. Sardjito dalam kategori baik.

Untuk mengetahui hubungan variabel luar dengan kualitas hidup penderita kanker serviks yang telah melakukan histerektomi radikal di RSUP Dr. Sardjito, dilakukan analisis dengan uji korelasi Spearman karena mengkorelasikan data katagori dengan data numerik.

Tabel 3. Hubungan variabel luar dengan status kesehatan global (kualitas hidup) wanita penderita kanker serviks yang telah dilakukan histerektomi radikal di RSUP Dr. Sardjito.

\begin{tabular}{|c|c|c|c|c|c|c|}
\hline \multicolumn{2}{|c|}{ Variabel Luar } & \multicolumn{3}{|c|}{ Kesehatan global } & $\begin{array}{c}r \\
0,047\end{array}$ & $\begin{array}{c}\mathbf{P} \\
0,732\end{array}$ \\
\hline Umur & $\begin{array}{l}26-35 \text { tahun } \\
36-45 \text { tahun } \\
46-55 \text { tahun } \\
56-65 \text { tahun } \\
>65 \text { tahun }\end{array}$ & $\begin{array}{l}90,00 \\
85,65 \\
85,32 \\
90,74 \\
91,67\end{array}$ & $\begin{array}{l} \pm \\
\pm \\
\pm \\
\pm \\
\pm\end{array}$ & $\begin{array}{l}9,13 \\
5,58 \\
8,29 \\
8,78 \\
8,33\end{array}$ & 0,047 & 0,732 \\
\hline Paritas & $\begin{array}{l}0 \\
1-2 \\
3-4 \\
\geq 5\end{array}$ & $\begin{array}{l}83,33 \\
87,33 \\
87,68 \\
86,11\end{array}$ & $\begin{array}{l} \pm \\
\pm \\
\pm \\
\pm\end{array}$ & $\begin{array}{r}11,79 \\
7,65 \\
7,48 \\
4,81\end{array}$ & 0,089 & 0,515 \\
\hline IMT & $\begin{array}{l}\text { underweight }(<18,5) \\
\text { normal }(18,5-24,9) \\
\text { overweight }(>24,9)\end{array}$ & $\begin{array}{l}94,44 \\
86,49 \\
86,98\end{array}$ & $\begin{array}{l} \pm \\
\pm \\
\pm\end{array}$ & $\begin{array}{l}9,62 \\
7,94 \\
6,78\end{array}$ & $-0,083$ & 0,542 \\
\hline Jenis Histopatologi & $\begin{array}{l}\text { Ca sel Squamous } \\
\text { Adenokarsinoma }\end{array}$ & $\begin{array}{l}88,48 \\
84,85\end{array}$ & $\begin{array}{l} \pm \\
\pm\end{array}$ & $\begin{array}{l}7,68 \\
7,56\end{array}$ & $-0,229$ & 0,090 \\
\hline Grade & $\begin{array}{l}\text { Baik } \\
\text { Sedang } \\
\text { Buruk }\end{array}$ & $\begin{array}{l}86,27 \\
87,68 \\
86,98\end{array}$ & $\begin{array}{l} \pm \\
\pm \\
\pm\end{array}$ & $\begin{array}{l}8,30 \\
7,89 \\
7,43\end{array}$ & 0,015 & 0,914 \\
\hline Keterlibatan KGB & $\begin{array}{l}\text { Ya } \\
\text { Tidak }\end{array}$ & $\begin{array}{l}81,25 \\
88,02\end{array}$ & $\begin{array}{l} \pm \\
\pm\end{array}$ & $\begin{array}{l}3,86 \\
7,86\end{array}$ & 0,349 & $0,008 *$ \\
\hline LVSI & $\begin{array}{l}\text { Ya } \\
\text { Tidak }\end{array}$ & $\begin{array}{l}83,33 \\
87,86\end{array}$ & $\begin{array}{l} \pm \\
\pm\end{array}$ & $\begin{array}{l}3,93 \\
8,19\end{array}$ & 0,232 & 0,085 \\
\hline Kemoterapi adjuvant & $\begin{array}{l}\text { Ya } \\
\text { Tidak }\end{array}$ & $\begin{array}{l}87,72 \\
86,71\end{array}$ & $\begin{array}{l} \pm \\
\pm\end{array}$ & $\begin{array}{l}8,04 \\
7,72\end{array}$ & $-0,037$ & 0,786 \\
\hline Stadium Kanker Serviks & $\begin{array}{l}\text { IA } \\
\text { IB } \\
\text { IB2 } \\
\text { IIA } \\
\text { IIA1 } \\
\text { IIA2 }\end{array}$ & $\begin{array}{l}83,33 \\
85,42 \\
83,33 \\
88,10 \\
83,33 \\
89,29\end{array}$ & $\begin{array}{l} \pm \\
\pm \\
\pm \\
\pm \\
\pm \\
\pm\end{array}$ & $\begin{array}{r}0,00 \\
8,33 \\
0,00 \\
8,00 \\
- \\
7,93\end{array}$ & 0,164 & 0,227 \\
\hline
\end{tabular}

Dari tabel 3 diatas hasil korelasi antara usia, paritas, indek massa tubuh (IMT), stadium kanker dan kemoterapi adjuvant menunjukkan tidak ada hubungan yang bermakna antara status kesehatan global dengan kualitas hidup ( $p>0,05)$. Rata-rata kualitas hidup pada pasien yang tidak adanya keterlibatan kelenjar getah bening (KGB) 88,02\% lebih tinggi dibandingkan dengan yang terlibat KGB $81,25 \%$ dengan nilai $p=0,008$ yang menunjukkan ada hubungan yang bermakna antara kesehatan secara global dengan keterlibatan KGB. 
Tabel 4. Pengaruh variabel luar terhadap kualitas hidup

\begin{tabular}{|c|c|c|c|c|c|c|c|c|}
\hline & & \multicolumn{4}{|c|}{ Kualitas Hidup } & \multirow{3}{*}{$\mathbf{P}$} & \multirow{3}{*}{$\mathbf{R} \mathbf{R}$} & \multirow{3}{*}{$\mathrm{Cl} 95 \%$} \\
\hline \multirow{2}{*}{\multicolumn{2}{|c|}{ Variabel Luar }} & \multicolumn{2}{|c|}{ Tinggi } & \multicolumn{2}{|c|}{ Rendah } & & & \\
\hline & & $\mathbf{n}$ & $\%$ & $\mathbf{n}$ & $\%$ & & & \\
\hline Umur & $\begin{array}{l}\leq 55 \text { tahun } \\
>55 \text { tahun }\end{array}$ & $\begin{array}{l}20 \\
10\end{array}$ & $\begin{array}{l}45,5 \% \\
83,3 \%\end{array}$ & $\begin{array}{r}24 \\
2\end{array}$ & $\begin{array}{l}54,5 \% \\
16,7 \%\end{array}$ & 0,020 & 0,545 & $0,36-0,82$ \\
\hline Menopause & $\begin{array}{l}\text { Ya } \\
\text { Tidak }\end{array}$ & $\begin{array}{l}14 \\
16\end{array}$ & $\begin{array}{l}63,6 \% \\
47,1 \%\end{array}$ & $\begin{array}{r}8 \\
18\end{array}$ & $\begin{array}{l}36,4 \% \\
52,9 \%\end{array}$ & 0,224 & 1,352 & $0,84-2,17$ \\
\hline Paritas & $\begin{array}{l}<3 \\
\geq 3\end{array}$ & $\begin{array}{l}13 \\
17\end{array}$ & $\begin{array}{l}43,3 \% \\
65,4 \%\end{array}$ & $\begin{array}{r}17 \\
9\end{array}$ & $\begin{array}{l}56,7 \% \\
34,6 \%\end{array}$ & 0,099 & 0,405 & $0,13-1,19$ \\
\hline katIMT & $\begin{array}{l}\text { Normal } \\
\text { Tidak normal }\end{array}$ & $\begin{array}{l}20 \\
10\end{array}$ & $\begin{array}{l}54,1 \% \\
52,6 \%\end{array}$ & $\begin{array}{r}17 \\
9\end{array}$ & $\begin{array}{l}45,9 \% \\
47,4 \%\end{array}$ & 0,920 & 1,027 & $0,61-1,73$ \\
\hline Jenis Histopatologi & $\begin{array}{l}\text { Ca sel Squamous } \\
\text { Adenokarsinoma }\end{array}$ & $\begin{array}{r}21 \\
9\end{array}$ & $\begin{array}{l}61,8 \% \\
40,9 \%\end{array}$ & $\begin{array}{l}13 \\
13\end{array}$ & $\begin{array}{l}38,2 \% \\
59,1 \%\end{array}$ & 0,126 & 1,510 & $0,85-2,66$ \\
\hline Grade & $\begin{array}{l}\text { Baik } \\
\text { Sedang } \\
\text { Buruk }\end{array}$ & $\begin{array}{r}10 \\
12 \\
8\end{array}$ & $\begin{array}{l}62,5 \% \\
52,2 \% \\
47,1 \%\end{array}$ & $\begin{array}{r}6 \\
11 \\
9\end{array}$ & $\begin{array}{l}37,5 \% \\
47,8 \% \\
52,9 \%\end{array}$ & 0,663 & & \\
\hline Keterlibatan KGB & $\begin{array}{l}\text { Ya } \\
\text { Tidak }\end{array}$ & $\begin{array}{l}12 \\
18\end{array}$ & $\begin{array}{l}48,0 \% \\
58,1 \%\end{array}$ & $\begin{array}{l}13 \\
13\end{array}$ & $\begin{array}{l}52,0 \% \\
41,9 \%\end{array}$ & 0,453 & 0,83 & $0,49-1,37$ \\
\hline LVSI & $\begin{array}{l}\text { Ya } \\
\text { Tidak }\end{array}$ & $\begin{array}{r}4 \\
26\end{array}$ & $\begin{array}{l}30,8 \% \\
60,5 \%\end{array}$ & $\begin{array}{r}9 \\
17\end{array}$ & $\begin{array}{l}69,2 \% \\
39,5 \%\end{array}$ & 0,060 & 0,51 & $0,22-1,19$ \\
\hline Kemoterapi adjuvan & $\begin{array}{l}\text { Ya } \\
\text { Tidak }\end{array}$ & $\begin{array}{r}9 \\
21\end{array}$ & $\begin{array}{l}42,9 \% \\
60,0 \%\end{array}$ & $\begin{array}{l}12 \\
14\end{array}$ & $\begin{array}{l}57,1 \% \\
40,0 \%\end{array}$ & 0,213 & 0,71 & $0,41-1,25$ \\
\hline $\begin{array}{l}\text { Stadium Kanker } \\
\text { Serviks }\end{array}$ & $\begin{array}{l}\text { IA } \\
\text { IB1 } \\
\text { IB2 } \\
\text { IIA1 } \\
\text { IIA2 }\end{array}$ & $\begin{array}{r}1 \\
10 \\
1 \\
13 \\
5\end{array}$ & $\begin{array}{l}50,0 \% \\
66,7 \% \\
33,3 \% \\
50,0 \% \\
50,0 \%\end{array}$ & $\begin{array}{r}1 \\
5 \\
2 \\
13 \\
5\end{array}$ & $\begin{array}{l}50,0 \% \\
33,3 \% \\
66,7 \% \\
50,0 \% \\
50,0 \%\end{array}$ & 0,787 & & \\
\hline
\end{tabular}

Pada tabel 4 didapatkan bahwa perbedaan bermakna yang berpengaruh signifikan terhadap kualitas hidup adalah umur $p=0,020 \quad(p<0,05)$ dengan $R R=0,545$ yang berarti umur $<55$ tahun yang memiliki kualitas hidup yang tinggi hanya 0,545 kali dibandingkan umur $>55$ tahun.

Tabel 5. Analisis multivariabel terhadap kualitas hidup

\begin{tabular}{llccc}
\hline & Variabel & P & OR & CI 95\% \\
\hline Umur & $\begin{array}{l}\leq 55 \text { tahun } \\
>55 \text { tahun }\end{array}$ & 0,040 & 0,09 & $0,01-0,90$ \\
Menopause & $\begin{array}{l}\text { Ya } \\
\text { Tidak }\end{array}$ & 0,435 & 0,531 & $0,11-2,60$ \\
Paritas & $<3$ & & & \\
Histopatologi & $\geq 3$ & 0,375 & 0,567 & $0,16-1,99$ \\
LVSI & $\begin{array}{l}\text { Ca sel Squamous } \\
\text { Adenokarsinoma }\end{array}$ & 0,380 & 1,74 & $0,51-5,96$ \\
Kemoterapi adjuvant & $\begin{array}{l}\text { Ya } \\
\text { Tidak }\end{array}$ & 0,112 & 0,266 & $0,05-1,36$ \\
& Ya & & & \\
\hline
\end{tabular}


Dari hasil analisis multivariabel, didapatkan data bahwa umur penderita kanker serviks memberikan pengaruh yang bermakna terhadap kualitas hidup. Hal ini ditunjukkan pada tabel 5 didapatkan nilai OR dari variabel umur adalah 0,09 yang artinya bahwa penilaian kualitas hidup 1 tahun pada pasien dengan umur $\leq 55$ tahun memiliki kualitas hidup 0,09 kali lebih tinggi dibandingkan dengan umur $>55$ tahun.

Dalam penelitian ini didapatkan bahwa sebagian penderita kanker serviks berumur 46-55 tahun dengan cut off point kurang dari 55 tahun (44/78,6\%), hal ini didasarkan pada acuan pembagian katagori umur berdasarkan DEPKES RI tahun 2009. Stadium terbanyak adalah stadium IIA1 $(26 / 46,4 \%)$ dengan jenis histopatologi terbanyak adalah karsinoma sel squamosa (34/60,7\%). Hal ini sesuai dengan penelitian Manetta dan Alberto sebelumnya dimana penderita kanker serviks terbanyak pada usia kurang dari 60 tahun (78\%) dengan rerata usia wanita penderita kanker serviks 52 tahun dan jenis histopatologi kanker serviks adalah karsinoma sel squamosa (85\%)..$^{5}$ Pada penelitian ini paritas yang didapatkan antara 1-2 sebanyak 25 orang, berbeda dengan penelitian terdahulu dimana paritas yang tinggi dapat memicu terjadinya kanker serviks. ${ }^{6} \mathrm{Hal}$ ini terjadi oleh karena terdapat kemungkinan pasien kanker serviks yang menjadi subyek penelitian sudah menjalani KB dengan tepat.

Kemoterapi adjuvan dilakukan pada pasien dengan katagori IB2 dan IIA2 dimana terdapat massa tumor serviks dengan ukuran lebih dari $4 \mathrm{~cm}$ (bulky tumor). Kemoterapi adjuvan yang diberikan pada pasien kanker serviks sebelum dilakukan tindakan histerektomi radikal efektif menurunkan ukuran massa tumor serviks, dan meningkatkan tingkat kelangsungan hidup bebas tumor. ${ }^{7}$ Untuk keterlibatan LVSI pada pasien yang mendapatkan kemoterapi adjuvan bermakna pada penelitian ini, dikarenakan tidak dapat diketahui saat preoperasi, sehingga ada kemungkinan keterlibatan LVSI sudah berlangsung sejak lama.

Berdasar hasil analisis penelitian menunjukkan bahwa rata-rata kualitas hidup penderita kanker serviks yang telah melakukan histerektomi radikal di RSUP Dr. Sardjito berada dalam kategori baik yang ditunjukkan pada status kesehatan secara umum sebesar $87,5 \%$ dan pada domain skala fungsi dan skala gejala lebih dari $90 \%$. Pada skala fungsi yang paling dominan adalah fungsi peran dan fungsi sosial. Pasien yang telah menjalani histerektomi radikal biasanya sangat mengkhawatirkan kesehatan mereka. Dukungan sosial dan penghargaan terhadap pasien kanker serviks sangat penting untuk mendapatkan kualitas hidup yang tinggi. Pada skala gejala pasien kanker serviks yang menjalani histerektomi radikal sedikit mengalami kelelahan dan rasa sakit dikarenakan efek samping dari pengobatan radiasi dan kemoterapi. ${ }^{8}$ Pasien yang telah menjalani histerektomi radikal tidak mengalami kesulitas keuangan dikarenakan semua pasien kanker serviks memakai jaminan kesehatan.

Dilihat dari korelasi antara variabel luar dengan kualitas hidup secara keseluruhan, diketahui bahwa kelenjar getah bening memiliki hubungan yang bermakna terhadap kualitas hidup dimana didapatkan nilai $p=0,008$ yang artinya bahwa apabila terdapat keterlibatan atau metastasis ke KGB maka survival rate 5 sampai 20 tahun adalah $74 \%$ tergantung pada jumlah, ukuran dan lokasi dari metastasis. Kemudian pada jenis histopatologi, stadium kanker, keterlibatan LVSI, baik yang telah mendapatkan kemoterapi adjuvan maupun tidak, diketahui bahwa pasien kanker serviks yang telah menjalani histerektomi radikal memiliki kualitas hidup yang baik.

Dari analisis bivariat dan multivariat ditemukan perbedaan yang bermakna secara statistik pada kelompok usia ditemukan nilai $p=0,020 \quad(p<0,05)$ dengan $R R=0,545$. Akan tetapi tidak berbeda secara klinis pada tingkatan kualitas hidup, hanya saja untuk domain fungsi sosial pasien dengan usia lebih tua (>55 tahun) memberikan laporan fungsi sosial lebih buruk daripada pasien yang lebih muda. ${ }^{9}$

\section{KESIMPULAN DAN SARAN}

Pada penelitian ini dapat disimpulkan bahwa kualitas hidup satu tahun pasien kanker serviks yang telah dilakukan histerektomi radikal di RSUP Dr. Sardjito Yogyakarta tinggi, sehingga tindakan dan pengobatan pada pasien kanker serviks stadium awal di RSUP Dr. Sardjito sudah tepat. Hanya terdapat perbedaan yang cukup signifikan terhadap kualitas hidup berdasarkan umur dan terjadi keterlibatan kelenjar getah bening (KGB). 


\section{DAFTAR PUSTAKA}

1. Colombo, N., Carinelli, S., Colombo, A., Marini, C., Rollo, D., Sessa, C. and ESMO Guidelines Working Group, 2012a. Cervical cancer: ESMO Clinical Practice Guidelines for diagnosis, treatment and follow-up. Annals of oncology, 23 ( suppl_7 ), vii27vii32.

2. Chatterjee, D. and Bandyopadhyay, A.R., 2015. A preliminary study on perception of Cervical cancer. International Journal of Scientific and Research Publications.

3. Lowy, D.R. and Schiller, J.T., 2012. Reducing HPV - associated cancer globally. Cancer prevention research, 5( 1), 18-23.

4. Endarti, D., Riewpaiboon, A., Thavorncharoensap, M., Praditsitthikorn, N., Hutubessy, R. and Kristina, S.A., 2015. Evaluation of health-related quality of life among patients with cervical cancer in Indonesia. Asian Pac J Cancer Prev, 16(8), 3345-50.

5. Siswosudarmo, R., 2015. Pendekatan praktis penelitian epidemiologi klinis dan aplikasi SPSS untuk analisis statistika.

6. Schorge JO, Scaffer JI, Halvorson LM, Hoffman BL, Bradshaw KD, Cunningham FG, editors. (2008). Williams gynecology. Dallas: McGaw-Hill; 468, 646664.
7. Moreno, V., Bosch, F.X., Muñoz, N., Meijer, C.J., Shah, K.V., Walboomers, J.M., Herrero, R., Franceschi, S. and International Agency for Research on Cancer (IARC) Multicentric Cervical Cancer Study Group, 2002. Effect of oral contraceptives on risk of cervical cancer in women with human papillomavirus infection: the IARC multicentric case-control study. The Lancet, 359( 9312 ), 1085-1092.

8. Cho, Y.H., Kim, D.Y., Kim, J.H., Kim, Y.M., Kim, Y.T. and Nam, J.H., 2009. Comparative study of neoadjuvant chemotherapy before radical hysterectomy and radical surgery alone in stage IB2-IIA bulky cervical cancer. Journal of gynecologic oncology, 20(1), 2227.

9. Lai, B.P., Tang, C.S.K. and Chung, T.K., 2009. Agespecific correlates of quality of life in Chinese women with cervical cancer. Supportive Care in Cancer, 17(3), 271-278.

10. Khalil, J., Bellefqih, S., Sahli, N., Afif, M., Elkacemi, H., Elmajjaoui, S., Kebdani, T. and Benjaafar, N., 2015. Impact of cervical cancer on quality of life: beyond the short term ( Results from a single institution ). Gynecologic oncology research and practice, 2(1), 7. 